\title{
Framing Entangled Legalities beyond the State
}

\author{
NICO KRISCH
}

\subsection{Introduction}

Law tends to make its appearance in the singular. We think of a legal order as a relatively integrated whole, as a system in which the different parts play a defined role and display a certain amount of coherence, if only because there are rules that regulate what happens when different norms conflict and because there are judges to decide unclear cases. We also expect law to be coherent and orderly as a matter of normative judgement - under the rule of law, we need to be able to know what the law requires from us. The unitary legal system then appears as both an analytical frame and an evolutionary achievement.

Yet in many contexts, law does not actually appear in the singular but in the plural. Norms from different origins become relevant in the same situation, and they often come with divergent prescriptions or at least orientations. Their relations are not predefined but remain to be determined through the social interplay of actors. State law interacts with local, Indigenous and religious law; norms from international and transnational law are used alongside domestic law and national regulation. These norms are not limited to neatly separated spheres but instead often address, directly or indirectly, the same set of actors and the same kind of behaviour. Yet they do not form part of a common legal order - they are entangled rather than integrated.

Such entanglement is the focus of the present volume. We regard entanglement as a common state of affairs in law - and likely a more common one than legal 'systems' with aspirations of hierarchy, order and coherence, as depicted in the standard image of law in the context of the modern, Western nation state. Legal entanglement was typical before the modern state arose, has been present within many states throughout, and 
has arguably increased with the rise in importance of transnational and international rules.

In this volume, we focus primarily on contemporary forms of entanglement, with a particular eye on encounters 'beyond' the state, both in the relation of state law with non-state law (especially of an Indigenous or religious kind) as well as the relation of different legalities in the transnational sphere. We inquire into the contexts in which entanglement occurs: the different bodies of norms, institutions and actors involved, as well as the dynamics they create. We also inquire into the legal forms it generates: the ways in which actors construe the relations between different norms, which are increasingly central to defining the shape of the overall order. And we are interested in the consequences entanglement has for conceptions of legal order more broadly - how do we need to adjust our understanding of 'law' if it is entangled rather than systemic?

This framing chapter sets the scene for the volume by defining key concepts, developing the theoretical frame and setting out the questions and problématiques animating the volume while highlighting the contributions of the different chapters. It begins by clarifying the concept of 'entanglement' in law (Section 1.2) and then explores some historical instantiations to generate a backdrop against which to theorize its contemporary forms (Section 1.3). The chapter then develops expectations as to where we can observe entanglement and what the actors and dynamics behind it are (Section 1.4). It outlines a typology of the legal forms in which we can expect entanglement to be reflected (Section 1.5), and then lays out some implications of entangled legalities for our conceptualization of legal order (Section 1.6).

\subsection{Legal Entanglement}

The notion of entanglement is not typically used in the legal context. It is common in quantum physics where it denotes a phenomenon in which different particles relate to one another in such a way that the 'state of each of them cannot be described independently of the state of the other(s)'. In a related vein, in the study of history the notion of 'entangled histories' has come to emphasize the importance of relations between interconnected societies. This approach was originally driven

${ }^{1}$ See Wikipedia entry on 'quantum entanglement', https://en.wikipedia.org/wiki/Quantum_ entanglement. 
by the insight that the histories of European and extra-European societies cannot be understood without taking into account the continuous connections between them. ${ }^{2}$ Unlike comparative approaches which inquire into similarities and differences, entangled histories are interested in processes of mutual influencing, in reciprocal or asymmetric perceptions, in entangled processes of constituting one another, ${ }^{3}$ and especially in 'the constitutive role which the interaction between Europe and the extra-European world has played for the specificities of modernity in the different societies.'

Similarly, the idea of histoire croisée focuses on intercrossings between different objects of inquiry - intercrossings that potentially transform these objects themselves. ${ }^{5}$ In cultural studies more broadly (and well beyond the particular focus on postcoloniality), the notion of cultural entanglements has been used to highlight 'the aspects of agency, processuality and the creation of something new which is more than just an addition of its origins' from different contexts, and the importance of liminal spaces in which different cultures come into particularly close encounters. ${ }^{6}$

In the study of law, proponents of legal pluralism have done most to trace 'entanglements' between different legal orders, even if they have not always called them thus. ${ }^{7}$ The first phase of legal pluralism often focused on the simultaneous, parallel existence of different legal systems in the same social field, often with an eye on the relationship of formal and informal law, state law and custom, particularly in traditional societies. This gave way over time to a broader appreciation of similar phenomena in other contexts, including states in the Global North. Later pluralist scholarship also moved away from an image of separate legalities and

${ }^{2}$ S. Randeria, 'Geteilte Geschichte und verwobene Moderne', in N. Jegelka, H. Leitgeb, and J. Rüsen (eds), Zukunftsentwürfe: Ideen für eine Kultur der Veränderung (Campus Verlag, 1999), pp. 87-96.

3 J. Kocka, 'Comparison and Beyond' (2003) 42 History and Theory 39-44, at 42.

${ }^{4}$ S. Conrad and S. Randeria, 'Einleitung: Geteilte Geschichten - Europa in einer postkolonialen Welt', in S. Conrad, S. Randeria and R. Roemhild (eds), Jenseits des Eurozentrismus (Campus Verlag, 2013), pp. 32-70, at p. 40.

5 M. Werner and B. Zimmermann, 'Beyond Comparison: Histoire Croisée and the Challenge of Reflexivity' (2006) 45 History and Theory 30-50, at 38.

${ }^{6}$ P. W. Stockhammer, 'Conceptualizing Cultural Hybridization in Archaeology', in P. W. Stockhammer (ed.), Conceptualizing Cultural Hybridization: A Transdisciplinary Approach (Springer, 2011), pp. 43-58, at pp. 47-8.

${ }^{7}$ K. Günther and S. Randeria, Recht, Kultur und Gesellschaft im Prozess der Globalisierung (Programmbeirat der Werner Reimers Konferenzen, 2001), p. 85. 
came to stress the 'complex and interactive relationship' between different forms of ordering and their intertwined nature. ${ }^{8}$ Some authors have found intersecting legalities, or 'interlegality', to be the condition of postmodern law. ${ }^{9}$

In recent years, in a 'third phase' of legal pluralism, these approaches have found broader application to law under conditions of globalization, taking into more direct view relations between domestic, international and transnational law. ${ }^{10}$ The connections between these three phases, or approaches, are not always clear-cut, and in Chapter 17 Brian Z. Tamanaha highlights the discontinuities as well as the problems in borrowing from the two former to inform the latter approach. Legal historians, too, have begun to inquire more closely into legal entanglements. Inspired by frames from the study of history, the emphasis of this historical work is on openness, entanglement being seen as characterized by 'complex intertwined networks, with no beginning and no end, and a difficulty to fix the own point of departure.' ${ }^{11}$

This passage suggests, as in much of legal pluralist writing and works on interlegality, that the entanglements that come into focus here are primarily about mutual de facto influences and the travelling content of legal norms. Legal transplants and the substantive reception of legal forms and institutions are recurring themes, ${ }^{12}$ in a somewhat similar way to archaeologists studying the material entanglement of objects that are created in imitation of, and borrowing from, foreign examples. ${ }^{13}$ The perspective tends to be that of an outside observer tracing such influences, even if the participants in legal discourse (or the different legal

8 S. E. Merry, 'Legal Pluralism' (1988) 22 Law \& Society Review 869-96, at 873; J. Griffiths, 'What Is Legal Pluralism?' (1986) 18 The Journal of Legal Pluralism and Unofficial Law $1-55$, at $17-18$.

9 B. de Sousa Santos, 'Law: A Map of Misreading - Toward a Postmodern Conception of Law' (1987) 14 Journal of Law and Society 1279-302; B. de Sousa Santos, Toward a New Legal Common Sense: Law, Globalization, and Emancipation (Cambridge University Press, 2002).

${ }^{10}$ Günther and Randeria, Recht, Kultur und Gesellschaft im Prozess der Globalisierung; R. Michaels, 'Global Legal Pluralism' (2009) 5 Annual Review of Law \& Social Science 1-35; P. Zumbansen, 'Transnational Legal Pluralism' (2010) 1 Transnational Legal Theory 141-89; P. S. Berman, Global Legal Pluralism: A Jurisprudence of Law Beyond Borders (Cambridge University Press, 2012).

11 T. Duve, 'Entanglements in Legal History: Introductory Remarks', in T. Duve (ed.), Entanglements in Legal History: Conceptual Approaches (Max Planck Institute for European Legal History, 2014), pp. 3-25, at p. 8.

12 Duve (ed.), Entanglements in Legal History.

13 Stockhammer, 'Conceptualizing Cultural Hybridization in Archaeology', p. 50. 
discourses intersecting here) continue to emphasize traditional frames. ${ }^{14}$ Many pluralists have long lamented the fact that legal discourse ignored such growing mutual influences and remained wedded to ideas of closed, unitary legal orders. ${ }^{15}$

Yet also from the perspective of the actors involved in them, legal orders have always had aspects defining their relations with other bodies of norms. Conflict-of-law norms for foreign law and norms about the reception of international law in domestic legal orders are the most prominent examples. ${ }^{16}$ If anything, globalization has enhanced the pressure on defining and developing these interface norms further - the global universe of norms is ever more populated, with overlapping norms and authority spheres in many, if not most, issue areas. Participants in legal discourses can choose to ignore this multiplicity and merely focus on their own legal order, but when other norms have strong social backing ignoring them can be costly in terms of legitimacy and often also compliance. In a context of multiplicity, defining relations becomes central for actors to stake out their positions. ${ }^{17}$

As a result, bodies of norms become 'entangled' not only as a matter of fact, but also in discursive construction. It is such connections which we, unlike much of the classical pluralist literature, take into focus in this volume. Actors - litigants, judges, dispute settlers, observers, addressees make claims about the relation of norms from different backgrounds, and they thus define and redefine the relative weights and interconnection between the norms at play. They also define the extent to which norms are perceived to form part of broader assemblages - in the relatively stable and firm mode of modern state legal orders, or in more porous ways, with a more open interplay of norms and characterized more through their linkages across boundaries than any strong form of belonging to an order as such. ${ }^{18}$ The production of tertiary

${ }^{14}$ Günther and Randeria, Recht, Kultur und Gesellschaft im Prozess der Globalisierung.

${ }^{15}$ See, e.g., G. Teubner, 'The King's Many Bodies: The Self-Deconstruction of Law's Hierarchy' (1997) 31 Law \& Society Review 763-88.

16 See Chapter 16 by Michaels.

17 See also M. Delmas-Marty, Ordering Pluralism: A Conceptual Framework for Understanding the Transnational Legal World (Bloomsbury, 2009); N. Krisch, Beyond Constitutionalism: The Pluralist Structure of Postnational Law (Oxford University Press, 2010), chapter 8.

18 The notion of 'bodies of norms' is meant to capture this possibility of looser assemblages, the boundaries and strength of which are themselves produced through discourses in and around law. It is also meant to capture that norms tend to come in clusters or patterns, especially when they are institutionally produced. 
norms - norms about the recognition of one legal order by another, as in Ralf Michaels' chapter - is one example here. The different contributions to the volume trace the ways in which relations between norms from different origins are construed in social practice - thus taking a primarily external perspective, though interested in the forms participants in legal discourses have at their disposal.

When we focus on legal entanglement here, we mean such discursive entanglement: the universe of statements that link different bodies of norms with one another. This is similar to the 'relational' (as opposed to 'material') entanglement in cultural studies: an entanglement in which the difference in origin remains visible even if the object is embedded in a different practice. ${ }^{19}$ In a context of growing multiplicity, this entanglement becomes stronger - where various norms are seen to apply to the same situation, actors will often be forced to clarify the relation they see between them, and we move towards a greater 'centrality of the margins. ${ }^{20}$ As actors engage in this practice, they also redefine the overall order as such: they construe the weight of different norms in that order, the relative strength of their claims over behaviour or institutions. And through this, they remake the law. If we understand law as ultimately socially constructed, ${ }^{21}$ a shift in the ways in which actors relate different parts of the legal order to one another reshapes the law itself.

Where entanglement is particularly pronounced, we might even end up in a situation in which - just as in quantum physics - 'the state of each [body of norms] cannot be described independently of the state of the other(s) ${ }^{\prime}{ }^{22}$ a situation of enmeshment, or even the creation of a new, hybrid form. But entanglement, in the way we use it here, remains distinct from full integration into a new form. Where norms are widely accepted as part of a common legal order, they are integrated rather than entangled. Likewise, when one body of norms is not linked with another by relevant actors, they remain separate. Entanglement comes in different degrees, but it sits between, and is distinct from, both separation and integration.

19 Stockhammer, 'Conceptualizing Cultural Hybridization in Archaeology', p. 50.

${ }^{20}$ N. Walker, 'Beyond Boundary Disputes and Basic Grids: Mapping the Global Disorder of Normative Orders' (2008) 6 International Journal of Constitutional Law 373-96.

${ }^{21}$ See, e.g., B. Z. Tamanaha, A General Jurisprudence of Law and Society (Oxford University Press, 2001).

${ }^{22}$ See Wikipedia entry on 'quantum entanglement', https://en.wikipedia.org/wiki/ Quantum_entanglement. 


\subsection{Entanglement before and around the State}

Entanglement was, by all accounts, a defining feature of many legal orders before the emergence and consolidation of the modern state. Even Roman law, often associated with system and coherence, is an impressive example of multiple fora, rules and practices, between which litigants and dispute settlers navigated their way. In Chapter 13, Caroline Humfress gives a vivid account of this complex interplay, tracing how actors reasoned out the application of different norms and, especially at the margins of the late Roman Empire, generated connected, but not integrated, legal orderings of their own.

Yet perhaps the most prominent expression of entangled legalities is to be found in medieval Europe. From the eleventh century onwards, law became increasingly systematized through legislation and codification, but the corpus iuris of much secular law was still made up of rules drawn ('received') from a wide variety of sources, including Roman law and customary usages. These rules retained their character as Roman law, ius commune, etc., but they were transformed through the reception process in a way that made them more compatible than they might have otherwise been. ${ }^{23}$ Codifications, reflections of the law applied on the ground, consequently contained elements from many different bodies of norms. The eleventh-century Usatges de Barcelona used rules of Visigoth and Roman origin just as well as secular and ecclesiastical ones; the German Sachsenspiegel of the early thirteenth century meshed an account of local custom with rules from imperial legislation and some from canon law. In the French law of the period, multiple local customs stood alongside royal law, with royal courts applying only those customs they deemed 'reasonable', often taking as guidance canon law or the learned Roman law taught at universities. ${ }^{24}$

Scholars have described the resulting structure as a 'patchwork of accommodations', in stark contrast with the idea of an integrated order or system. ${ }^{25}$ Judges in this structure could not merely rely on one set of rules but had to navigate between norms from a wide variety of contexts,

${ }^{23}$ H. J. Berman, Law and Revolution: The Formation of the Western Legal Tradition (Harvard University Press, 1983), p. 2.

24 Ibid., pp. 470-1, 504, 511.

${ }^{25}$ S. P. Donlan and D. Heirbaut, "A Patchwork of Accommodations": Reflections on European Legal Hybridity and Jurisdictional Complexity', in S. P. Donlan and D. Heirbaut (eds), The Laws' Many Bodies: Studies in Legal Hybridity and Jurisdictional Complexity, c1600-1900 (Duncker \& Humblot, 2015), p. 9. 
with greater emphasis on the substantive appropriateness of the rule finally chosen than on its pedigree. ${ }^{26}$ In their pragmatic ways, these judges inevitably entangled the multiple bodies of norms at play. This structure slowly gave way, with the emergence and consolidation of the modern nation state, to a focus on one, national law and the attempt to shape it through binding codifications. But the transition was winding and protracted, with many pockets of entanglement persisting for a long time. ${ }^{27}$ In Germany, for example, legal plurality continued to be prominent until the late nineteenth century. Judges based their decisions on a confluence of local laws, ius commune and various other sets of norms until the legislative and judicial unification of many areas of law after the creation of the German state. ${ }^{28}$

Entanglements remained particularly strong in borderlands in which different authorities and legal traditions intersected. French Flanders and the Roussillon, acquired by France from the Netherlands and Spain in the seventeenth century, experienced long periods of interwoven application of French laws, local customs and previously governing rules, thereby pursuing accommodation and avoiding clashes of authority. ${ }^{29}$ Yet more pronounced was multiplicity in imperial structures, inside and outside Europe. ${ }^{30}$ In the Holy Roman Empire, a prime example of jurisdictional complexity, the law applied was 'a mixture' of a variety of legal sources, meshing Roman and canon law with imperial prescriptions and

26 Donlan and Heirbaut, “'A Patchwork of Accommodations"”, p. 21.

27 See the contributions in Donlan and Heirbaut (eds), The Laws' Many Bodies.

${ }^{28}$ See N. Jansen, 'Law and Political Domination: Historical Observations, Conceptual Reflections, and Some Questions for Discussion' (2018) 16 International Journal of Constitutional Law 1176-85; M. Löhnig, 'Killing Legal Complexity: The Jurisprudence of the German Reichsgericht in the First Years of its Existence', in S. P. Donlan and D. Heirbaut (eds), The Laws' Many Bodies: Studies in Legal Hybridity and Jurisdictional Complexity, c1600-1900 (Duncker \& Humblot, 2015), pp. 249-70.

29 A. Wijffels, 'Ancien Régime France: Legal Particularism under the Absolute Monarchy', in S. P. Donlan and D. Heirbaut (eds), The Laws' Many Bodies: Studies in Legal Hybridity and Jurisdictional Complexity, c1600-1900 (Duncker \& Humblot, 2015), pp. 81-108; B. Durand, "Pluralism in France in the Modern Era - Between the "Quest for Justice" and "Uniformity Through the Law": The Case of Roussillon', in S. P. Donlan and D. Heirbaut (eds), The Laws' Many Bodies: Studies in Legal Hybridity and Jurisdictional Complexity, c1600-1900 (Duncker \& Humblot, 2015), pp. 169-92.

30 See L. Benton and R. J. Ross (eds), Legal Pluralism and Empires, 1500-1850 (New York University Press, 2013); J. Duindam, J. D. Harries, C. Humfress and H. Nimrod (eds), Law and Empire: Ideas, Practices, Actors (Brill, 2013). 
territorial and local rules. ${ }^{31}$ In the British Empire, jurists in England and abroad 'liberally mixed sources of common, civil, and natural law, principles of equity, and the law of nations' when grappling with colonial situations. ${ }^{32}$ Here and elsewhere, imperial and local legalities overlapped, and imperial subjects navigated the different bodies of norms and jurisdictions, often choosing sites and norms beneficial for them individually and creating 'relational fields' of law along the way. ${ }^{33}$

With the consolidation of the modern state, complexity and entanglement were reduced but not entirely suppressed. The 'cuts' between different elements of modern, liberal law, highlighted by Julia Eckert in Chapter 15, have also always been contested. 'Negotiations' between state and non-state law, traced in pluralist scholarship, persisted both in Europe and elsewhere, albeit with major variations. ${ }^{34}$ In recent decades, increasing societal diversity has sparked renewed interest in the relation of state and religious jurisdictions, especially on issues of family law. ${ }^{35}$ Such issues are often dealt with in a conflict-of-laws frame, with special attention to public policy exceptions, but they evoke larger issues of primacy between state law, human rights and religious precepts, as reflected in Tobias Berger's chapter on Bangladesh. The greater salience of these issues, especially in Western countries, stems in part from the rise of multicultural claims over the past decades. These claims have also directed renewed attention to the relation between state and Indigenous legal orders. ${ }^{36}$ In this collection, the contributions by Kirsten Anker

${ }^{31}$ P. Oestmann, 'The Law of the Holy Roman Empire of the German Nation', in H. Pihlajamäki, M.D. Dubber, and M. Godfrey (eds), The Oxford Handbook of European Legal History (2018), pp. 731-59.

32 R. J. Ross and P. J. Stern, 'Reconstructing Early Modern Notions of Legal Pluralism', in L. Benton and R. J. Ross (eds), Legal Pluralism and Empires, 1500-1850 (New York University Press, 2013), pp. 109-42, at p. 130.

${ }^{33}$ K. Barkey, 'Aspects of Legal Pluralism in the Ottoman Empire', in L. Benton and R. J. Ross (eds), Legal Pluralism and Empires, 1500-1850 (New York University Press, 2013), pp. 83-107, at pp. 94-103. See also S. E. Merry, 'Colonial Law and Its Uncertainties Forum: Maneuvering the Personal Law System in Colonial India: Comment' (2010) 28 Law and History Review 1067-72, at 1068.

34 Merry, 'Legal Pluralism'; M. A. Helfand (ed.), Negotiating State and Non-state Law: The Challenge of Global and Local Legal Pluralism (Cambridge University Press, 2015).

35 See, e.g., M. A. Helfand, 'Religious Arbitration and the New Multiculturalism: Negotiating Conflicting Legal Orders' (2011) 86 NYU Law Review 1231; M. Maclean and J. Eekelaar (eds), Managing Family Justice in Diverse Societies (Bloomsbury, 2013).

${ }^{36}$ See, e.g., J. Tully, Strange Multiplicity: Constitutionalism in an Age of Diversity (Cambridge University Press, 1995); K. Gover, Tribal Constitutionalism: States, Tribes, and the Governance of Membership (Oxford University Press, 2010). 
(Chapter 3) and by Keith Culver and Michael Giudice (Chapter 14) draw on this latter debate. They use the example of relations between the Canadian state and First Nations and trace how traditional, hierarchical legal conceptualizations can be, and are being, transformed into ones of entanglement.

The rise of transnational and international legalities over the past few decades has exacerbated the perceived multiplicity of legal orders and has helped to remove legal pluralism from the obscurity it long suffered in many mainstream accounts of law. ${ }^{37}$ One important driver for this development, especially for European scholars, has been the constitutional indeterminacy of the European Union. Protracted conflict between national constitutional courts and the European Court of Justice led many to diagnose a form of (constitutional) pluralism in Europe. ${ }^{38}$ For international lawyers, the long debate on fragmentation within the international legal order as well as the increasingly dense relations between domestic and international layers of law generated greater interest in the construction of these relations. ${ }^{39}$ Both as concerns the EU and international law, 'entanglement' is probably a better descriptor of complex realities than (integrated or separate) legal systems.

One important aspect of the new 'global legal pluralism' has been the broader focus on different kinds of legalities - formal and informal, public and private. ${ }^{40}$ The concept of law used in this debate typically goes beyond a traditional, Hartian frame and borrows from understandings used by legal pluralists with more anthropological backgrounds. The boundaries of the concept remain contested, and are often blurred, ${ }^{41}$ but they tend to include as a minimum institutional normative

37 See, e.g., Berman, Global Legal Pluralism.

${ }^{38}$ N. MacCormick, Questioning Sovereignty: Law, State, and Nation in the European Commonwealth (Oxford University Press, 1999); N. Krisch, 'Europe's Constitutional Monstrosity' (2005) 25 Oxford Journal of Legal Studies 321-34; G. De Búrca and J. H. Weiler (eds), The Worlds of European Constitutionalism (Cambridge University Press, 2011).

39 M. Koskenniemi, 'The Fate of Public International Law: Between Technique and Politics' (2007) 70 The Modern Law Review 1-30; J. E. Nijman and A. Nollkaemper (eds), New Perspectives on the Divide between National and International Law (Oxford University Press, 2007); Krisch, Beyond Constitutionalism.

${ }^{40}$ See, e.g., Berman, Global Legal Pluralism; N. Krisch, 'Pluralism in International Law and Beyond', in J. d'Aspremont and S. Singh (eds), Concepts for International Law: Contributions to Disciplinary Thought (Edward Elgar, 2019), pp. 691-707.

${ }^{41}$ See B. Z. Tamanaha, 'Understanding Legal Pluralism: Past to Present, Local to Global' (2008) 30 Sydney Law Review 375-411. 
orders' - bodies of norms associated with certain institutions, formal or informal, for their interpretation or enforcement. ${ }^{42}$ Customary and religious law form part of the 'law' on this account, just as many of the informal norms - soft law, standards, etc. - that are institutionally produced and monitored, accepted by actors in the respective fields as carrying significant weight, and are often more consequential than formal rules. ${ }^{43}$ It is such a broader understanding of law that underlies the present volume. Not all chapters necessarily employ the same approach - some have a focus on more formal norms, others stretch the notion of law well into non-normative forms of governance. ${ }^{44}$ Chapters 14 and 17 by Culver and Giudice and by Tamanaha are most explicit in theorizing the concept of law as such, and in many of the other chapters we can witness how the most consequential entanglements straddle the boundaries of formal law and create linkages with, and among, less formal legalities.

\subsection{Dynamics of Entanglement}

Entanglement is not the same everywhere. Some cultures have been shaped more, some less, by interactions with others, and so it is in law. Not all law is equally entangled - some legal relations are characterized by a high degree of interaction between different bodies of norms, others not. And while such interaction depends on legal multiplicity, on overlapping claims associated with norms from different origins, multiplicity is not sufficient to bring it about. Even where different, potentially competing norms are present, we may find them to be not entangled but integrated into a common whole, as in many federal states in which there is one legal order and federal law is recognized to trump legislation at the state level.

When we look beyond the state, it is not immediately clear why, in contexts of intense multiplicity, degrees of entanglement vary as much as they do. Contrast the European Union, where national and EU law have

42 See K. Culver and M. Giudice, Legality's Borders: An Essay in General Jurisprudence (Oxford University Press, 2010); M. Del Mar, 'Legality as Relative Institutionalisation: MacCormick's Diffusionism and Transnational Legal Theory' (2014) 5 Transnational Legal Theory 177-217.

43 N. Krisch, 'The Decay of Consent: International Law in an Age of Global Public Goods' (2014) 108 American Journal of International Law 1-40; J. Pauwelyn, R. Wessel and J. Wouters (eds), Informal International Lawmaking (Oxford University Press, 2012).

44 Contrast, for example, Chapters 4 and 6 by Backer and Kanetake. 
been deeply entangled since the 1960s, with the Andean Community where, despite a similarly strong central court and formal setup, national and community rules have remained far more distant. ${ }^{45}$ Or compare the differences across countries in the ways global women's rights relate to national legal discourses - sometimes kept at a distance, sometimes leading to mutual influences of a transformative kind. ${ }^{46}$ In all these cases, encounters would be possible in the liminal space of overlapping norms, but actual encounters do not always happen, and if they do they do so in widely varying forms and intensities.

Understanding such variation would require a detailed contextual analysis in each case, and it is bound to be impossible to generalize broadly across historical and institutional contexts. Tamanaha, for example, emphasizes in Chapter 17 the contrast between relations among legalities that reflect diversity in modes and visions of life - as between state law and customary law in many, especially postcolonial societies and legal multiplicity fostered by a proliferation of regulatory or adjudicatory institutions of more or less the same kind. But based on existing studies and the analyses in this volume, we can develop some observations and conjectures about the actors, pathways and dynamics through which legal entanglement comes about and develops.

\subsubsection{Actors}

On which path entanglement comes about (and whether it does) will always depend on the actors present and relevant in a given context - it is through them that entanglement is 'brought to life'. ${ }^{47}$ Relations between bodies of norms are often construed by judges and other dispute settlers, but not only or perhaps not even primarily. They are also built by lawmakers, such as governments formulating legislation and treaties defining the relation with other rules; by regulators devising common norms and drawing on them in their regulatory practice; by international organizations producing statements about the weight of one body of norms vis-à-vis another. This volume contains many

45 See, e.g., K. J. Alter and L. R. Helfer, 'Nature or Nurture? Judicial Lawmaking in the European Court of Justice and the Andean Tribunal of Justice' (2010) 64 International Organization 563-92.

${ }^{46}$ P. Levitt and S. E. Merry, 'Vernacularization on the Ground: Local Uses of Global Women's Rights in Peru, China, India and the United States' (2009) 9 Global Networks 441-61.

47 See especially Chapters 2 and 13 by Berger and Humfress. 
examples of this type, such as attempts by the Chinese government to entangle different legalities, transnationally through the Belt and Road Initiative and domestically through the social credit system, explored in Chapters 4 and 5 by Larry Catá Backer and Tomer Broude. International bodies are the focus of other contributions, as in Machiko Kanetake's account of the UN Human Rights Committee's efforts to create linkages with domestic courts in Chapter 6, or Grégoire Mallard and Aurel Niederberger's inquiry in Chapter 9 into the way in which norms on counter-proliferation finance are circulating between regulators and institutions such as the UN Security Council or the Financial Action Task Force.

Yet the scope of relevant actors goes well beyond the governmental sphere. As already noted in the imperial context, individual litigants often play key roles in determining by whom legal claims are decided, and they present arguments about which norms ought to apply and how. ${ }^{48}$ Lawyers advising clients generate understandings of how different laws relate; international law firms, in particular, are important producers of legal knowledge in this respect. ${ }^{49}$ Civil society groups, business associations and private norm addressees are often active in fostering views on how one body of norms interacts with another - they need to navigate a pluralist order, and their statements will have a particular weight in areas where more authoritative actors are absent. For example, as emerges from Eckert's chapter on struggles over rights violations in the context of global value chains, entanglement will often be driven by a 'mobilisation of law from below'. More generally, if we think of law as a social practice, it is a broad range of societal and official actors whose practices constitute legal orders and the relations of norms among them. ${ }^{50}$ Actors are situated, and this situation shapes their way of regarding the multiple norms at play. Where actors - for example dispute settlers - are closely tied to one body of norms, we can expect them to be more reticent bridge-builders than actors with a self-understanding that is less clearly defined. This is most obvious in the context of national courts. Where judges understand themselves as part of a state's authority structure, tasked first and foremost with applying that state's law, they are unlikely

48 See Chapter 13 by Humfress.

49 See also Günther and Randeria, Recht, Kultur und Gesellschaft im Prozess der Globalisierung, pp. 52-9.

50 See generally Chapter 17 by Tamanaha; and the emphasis on a 'user theory of jurisdiction' in Chapter 13 by Humfress. 
to draw openly on norms from other origins. ${ }^{51}$ However, not all national judges are alike. Common law judges, for example, might be more open than their civil law colleagues to creating linkages with norms from various sources out of an understanding of law that is encompassing rather than tied to a particular political authority. ${ }^{52}$ Which actors are tasked with resolving a particular conflict - and what background they have - will then often have strong repercussions for the kind and strength of resulting connections. Humfress' chapter, with its focus on the different engagements with Roman law by military officials, clerics and tribal leaders in the resolution of an individual dispute, brings this point out nicely.

Variations in situatedness might also help to explain, for example, the relative unwillingness of courts tasked with the interpretation of a particular instrument to consider norms from other origins, compared with the attempts of, say, the International Court of Justice to provide a (somewhat) more ecumenical reading of international law. ${ }^{53}$ A body tasked with the interpretation of less well-defined areas of law, such as the Court of Arbitration for Sport, is likely to sense greater freedom in creating linkages with norms from different origins. ${ }^{54}$ And dispute settlers who, like arbitrators appointed ad hoc, are not beholden to a particular political or legal order, can be expected to draw on a broader range of norms than their more directly committed counterparts.

Non-governmental actors - and especially those that are not tasked with enforcing a particular legal order - are more generally less committed in principle, and they are likely to be more flexible in using and drawing upon different legalities: they may perhaps be seen to inhabit the 'liminal spaces' in which entanglements tend to flourish. ${ }^{55}$ This is probably also true for actors who, like regulators, understand themselves as lawmakers rather than law-appliers and therefore may feel less

${ }^{51}$ See J. Resnik, 'Law as Affiliation: "Foreign" Law, Democratic Federalism, and the Sovereigntism of the Nation-State' (2008) 6 International Journal of Constitutional Law 33-66.

52 See Chapter 6 by Kanetake; also H. P. Glenn, 'Transnational Common Laws' (2005) 29 Fordham International Law Journal 457-71.

53 Y. Shany, 'International Courts as Inter-Legality Hubs', in J. Klabbers and G. Palombella (eds), The Challenge of Inter-Legality (Cambridge University Press, 2019), pp. 319-38. See also Corradini, Chapter 7, on investment tribunals.

54 See Chapter 10 by Duval.

55 On those liminal spaces, see Stockhammer, 'Conceptualizing Cultural Hybridization in Archaeology', pp. 45-51. 
constrained by considerations of what the law in force is on a given issue. Yet, as Broude highlights in Chapter 5, individual actors tend to approach the multiple legalities potentially relevant in a given situation from a particular, and highly bounded, perspective - their situatedness will often make them see, or prioritize, certain norms rather than others, and it is crucial to understand these perspectives for an account of how and why legalities become entangled (or not).

\subsubsection{Pathways}

There are many paths to entanglement, and the discussion so far has already suggested some important ones. The ideational context of actors most clearly in the case of judges - is bound to condition whether they construe legal orders as one or as separate, and whether they see them as open or closed. The space for and possibilities of entanglement are likely to vary historically and geographically as a result. For a judge in seventeenth-century Germany, entangling may have been the norm, whereas his late twentieth-century counterpart will have approached the plurality of norms through a prism of clearly separated (and internally integrated) legal spheres. Likewise, actors in many developing countries may be more used to navigating different normative orders than their colleagues in the Global North, even if there remains important variation. On the other hand, actors with a firm international law background applying formal international legal rules may be less open to applying norms from other sources than those engaged in the application of informal or transnational norms. The intense practice of linking norms from different origins by bodies such as the National Contact Points under the Organisation for Economic Co-operation and Development (OECD) Guidelines for Multinational Enterprises, traced by Tomáš Morochovič and Lucy Lu Reimers in Chapter 12, reflects a very open imagination of the law to be applied. At the same time, international lawyers will tend to regard different issue-specific regimes as part of one international legal order and seek to construe harmonious relations between them. ${ }^{56}$ That said, the communities of practice actors form part of will often shape the way they construe linkages; this comes out particularly clearly in Chapter 11 in Francesco Corradini's portrayal

${ }^{56}$ H. Birkenkötter, 'International Law as a Common Language across Spheres of Authority?' (2020) 9 Global Constitutionalism 318-42. 
of how investment and human rights communities differ in their construction of the nexus between norms from these areas. ${ }^{57}$

A second ideational pathway works through resonance. Norms from other origins may be appealing for their substantive content but also for the aura of progress they come with, the Zeitgeist they represent or the fit they produce with existing commitments. Likewise, the actors creating such norms may appear as appealing - as embodying the right values, as culturally superior, etc., sometimes as a result of hegemonic scripts. ${ }^{58}$ Linkage on this basis is, however, likely primarily when the norms in question resonate with norms and values in the target context. ${ }^{59}$ Such resonance does not only have to do with the 'actual' content of the respective norms but also, and perhaps primarily, with the ways in which those norms are framed and construed in societal and political discourses. If such construction allows enhancing beliefs and values that are already widely held, linkages succeed more easily, but they may come at the cost of greater distance from the way in which those norms are understood in the contexts they originate from.

Other pathways relate more directly to rational choices. Relevant actors often stand to gain from linkages between different bodies of norms - litigants, for example, may see the mobilization of law from a variety of sources as beneficial to their cause, as detailed in Eckert's chapter. They may also use them to relativize or circumvent unfavourable local norms or obtain advantageous remedies. ${ }^{60}$ Sometimes, they will be led to draw freely on relevant norms from different origins - state law, religious law, or international norms. ${ }^{61}$ In Berger's chapter on the entanglement of state and non-state law in Bangladesh, activists make liberal use of multiple normative registers, including religious and international law, to carve out space for marginalized actors.

57 See also S. Taekema, 'Between or beyond Legal Orders: Questioning the Concept of Legal Order in Light of Interlegality', in J. Klabbers and G. Palombella (eds), The Challenge of Inter-Legality (Cambridge University Press, 2019), pp. 69-88, at pp. 78, 84.

${ }^{58}$ See Chapter 15 by Eckert.

59 Levitt and Merry, 'Vernacularization on the Ground'; T. Berger, Global Norms and Local Courts: Translating the Rule of Law in Bangladesh (Oxford University Press, 2017).

${ }^{60}$ L. Benton, Law and Colonial Cultures: Legal Regimes in World History, 1400-1900 (Cambridge University Press, 2002) p. 137; Barkey, 'Aspects of Legal Pluralism in the Ottoman Empire', p. 100.

${ }^{61}$ See J. Eckert, 'What Is the Context in "Law in Context"?', in S. P. Donlan and L. Heckendorn Urscheler (eds), Concepts of Law: Comparative, Jurisprudential, and Social Science Perspectives (Routledge, 2016), pp. 225-36. 
Linkages with different bodies of norms can create space, but they can also serve to strengthen authority. For example, transnational regulators may enhance their own position by linking up with bodies of norms produced by other, reputed institutions, as detailed in Corradini's chapter on global financial regulation, and in particular the efforts of the Financial Stability Board, to weave a common set of norms. Another prominent example are national courts who, by linking their domestic legal order to European Community law, created space for themselves vis-à-vis political branches and hierarchically superior courts. $^{62}$ In Antoine Duval's chapter on the making of a transnational lex sportiva, it is the Court of Arbitration for Sport that bolsters its authority - and wards off potential challenges by other courts - by drawing together rules and laws of very different pedigree.

In this picture, stronger, more autonomous actors would likely be more resistant to closer entanglement, while weaker, more vulnerable ones would seek it to bolster their own position and authority. ${ }^{63}$ Corradini's chapter on investment and human rights law suggests that increasing legitimacy challenges for investment law might push actors, including arbitrators, to seek stronger entanglements, at least rhetorically. In contrast, Lucy Lu Reimers' chapter on international trade law shows how a relatively strong institution - the World Trade Organization (WTO) - has been able to use linkages strategically and selectively, while avoiding unfavourable entanglements. In Backer's chapter, algorithmic techniques of governance can subsume other legalities, but typically on their own terms and potentially dominating them as a consequence of technological change. Taking the different, competing norms into account may appear as the path of least resistance, but it may also help to create space to come to a preferred conclusion.

A further major pathway, too often neglected, is coercion, broadly conceived. Metropolitan law in imperial settings may have at times held some appeal or benefits, but in many cases local actors have woven it into their legal arguments because of a relation of domination - expressed, for example, through imperial judges who needed to relate 'their' law to the norms operative on the ground, or through local judges who thereby

62 K. J. Alter, Establishing the Supremacy of European Law: The Making of an International Rule of Law in Europe (Oxford University Press, 2001).

63 This may help to explain patterns in judicial borrowing by international courts; see E. Voeten, 'Borrowing and Nonborrowing among International Courts' (2010) 39 The Journal of Legal Studies 547-76. 
reaffirmed loyalty and obedience to imperial rulers. ${ }^{64}$ But coercion is not confined to the distant past. Today, for example, the adoption of World Bank rules on resettlement in the context of infrastructure programmes on the part of borrowing states is often a matter of conditionality and necessity rather than persuasion or attraction. ${ }^{65}$ In Chapter 11, Corradini points to the coercive aspects of conditionality in the implementation of international financial standards by the International Monetary Fund. Backer's chapter highlights hierarchical forms of entanglement in the Chinese social credit system as well as transnational credit rating agencies. Broude's chapter traces the imperial character of entanglements brought about by the Chinese Belt and Road Initiative. Mallard and Niederberger's contribution to this volume also stresses the coercive aspect as it traces the hegemonic origins of intertextual entanglements in the new legal order of counter-proliferation finance. In their compelling reading, the circulating references between different kinds of rules formal and informal, international and national - reinforce each other's authority but also serve to hide their origins in US policies.

\subsubsection{Dynamics}

Entanglements may be gradual and smooth, but often they are characterized by a dialectical dynamic - one in which actors favour proximity between different bodies of norms but they also seek a certain distance, and they thus construe the relation as neither strict separation nor full integration into one order. Just as processes of globalization are characterized by the dual tendencies of assimilation and fragmentation, entanglement is an in-between state which often oscillates between these poles. ${ }^{66}$

This is perhaps most obvious when entanglement comes about, at least in part, through coercion. Pressure to adopt certain norms is then likely to be countered by attempts to create distance at the same time, as in the case of local law faced with metropolitan legislation in (post)colonial

${ }^{64}$ See, e.g., Benton, Law and Colonial Cultures, chapter 4.

${ }^{65}$ See S. Randeria, 'The State of Globalization: Legal Plurality, Overlapping Sovereignties and Ambiguous Alliances between Civil Society and the Cunning State in India' (2007) 24 Theory, Culture \& Society 1-33.

${ }^{66}$ See Z. Bauman, 'On Glocalization: Or Globalization for some, Localization for some Others' (1998) 54 Thesis Eleven 37-49; Conrad and Randeria, 'Einleitung: Geteilte Geschichten', pp. 41-2. 
contexts. ${ }^{67}$ This is visible today, for example, in the continuing struggle of Indigenous peoples against the supremacy claims of (settler) state law or in attempts to counter state law demands by emphasizing the autonomy of Sharia law. ${ }^{68}$ But the tension between proximity and distance can be observed more widely. In the postnational context, it will often reflect a tension between factors militating for closer linkage - for example the harmonization of markets, or universal human rights claims - and an insistence on autonomy and the freedom to decide differently. The latter is relatively obvious in 'vertical' relations when actors insist on the autonomy of smaller units, for example national institutions vis-à-vis international rules. ${ }^{69}$ Kanetake's chapter shows how UN human rights bodies accommodate potential resistance by leaving national actors significant flexibility when it comes to giving international decisions domestic legal weight, and how national courts use (and sometimes extend) this space in a variety of ways. Approaching the question from the local angle, Berger's chapter traces the complex interplay between proximity and distancing in the approaches of different actors to multiple available norms, from Islamic to state and international human rights law, in debates over a ban on Islamic fatwas in Bangladesh.

Yet we can also observe an insistence on autonomy in other, more 'horizontal' contexts, for example when actors seek to defend the values driving international human rights law or international economic law from being contaminated by the respective other. ${ }^{70}$ Reimers' chapter on the interaction between international trade and environmental law provides a vivid account of this dynamic. The more particular bodies of norms are linked with distinct values, institutions and constituencies, the more linkages may create concerns about heteronomy and provoke calls for greater distance. In the end, the portrayal of certain relations as 'vertical' or 'horizontal' is also a product of how an entanglement is socially construed - as we can see, for example, in Culver and

${ }^{67}$ On the latter, see e.g. Barkey, 'Aspects of Legal Pluralism in the Ottoman Empire', pp. 101-3.

68 See Chapters 3, 14 and 17 by Anker, Culver and Giudice, and Tamanaha.

69 The 'vertical' and 'horizontal' dimensions of entanglement are helpful as heuristic tools to structure the inquiry, but it should be noted that they are themselves products of how the relation between different bodies of norms are related. Indigenous and state law, for example, can be understood as standing in either the one or the other relation; the politics of this choice are reflected in Chapter 14 by Culver and Giudice.

70 P. Alston, 'Resisting the Merger and Acquisition of Human Rights by Trade Law: A Reply to Petersmann' (2002) 13 European Journal of International Law 815-44. 
Giudice's discussion of the relation of Canadian state and indigenous laws in Chapter 14, the question of whether a relation should be seen as one or the other can be highly contested and consequential. Attempts at linkage can make entanglements appear as more vertical, attempts at distancing can make them more horizontal.

The need to create, or insist on, distance is likely to be, in part, a function of the character of the entangled norms. Where these are informal and soft, actors retain space and autonomy even in the face of close linkages. The examples of corporate social responsibility norms, in Morochovič and Reimers' chapter, or global financial standards, in Corradini's contribution, are cases in point here - as Corradini emphasizes, the creation of unified financial standards has long been hampered by an insistence on autonomy on the part of both national governments and various international bodies. In hard law contexts, for example in domestic courts, the stakes of entanglement will often be higher and a clear definition of relations more consequential.

The dialectic of proximity and distancing also has a temporal dimension. Linkages often have long-term effects, especially when they concern not only individual norms but whole sets of norms or legal orders. A norm defining the status of international law in the domestic legal order, for example, has relevance for an unlimited number of interactions between both legal orders in the future. The effects of such linkage, however, are often difficult to predict for the actors involved, and attention may well be drawn to them only when problems arise and a particular issue becomes politicized. ${ }^{71}$ As tighter forms of coupling emerge and come to apply to increasingly consequential and salient issues, they can be expected to provoke political contestation and resistance which will often seek to disrupt more routinized forms of interaction and may result in mechanisms for reclaiming distance. Even if issue-specific, this politicization may lead to calls for redefining the linkage more broadly. In this vein, contestation around issues of terrorism and voting rights for prisoners has engendered a general movement in the UK for greater distance from judgements of the European Court of Human Rights. ${ }^{72}$

${ }^{71}$ M. Zürn, M. Binder and M. Ecker-Ehrhardt, 'International Authority and Its Politicization' (2012) 4 International Theory 69-106.

72 See M. Madsen, 'The Challenging Authority of the European Court of Human Rights: From Cold War Legal Diplomacy to the Brighton Declaration and Backlash' (2016) 79 Law and Contemporary Problems 141-78, at 170-1. 


\subsection{A Variety of Forms}

If we can indeed expect a push towards greater proximity, accompanied by certain forms of distancing that prevent full integration, the result is likely to be the emergence of new types of norms at the interfaces between different parts of the legal order - norms that, instead of governing behaviour directly, define the relation and applicability of primary norms (on behaviour) as well as secondary norms (on powers to make and interpret the law). ${ }^{73}$ With this volume, we aim at gaining a clearer picture of the shape of these norms - 'tertiary norms', as Michaels describes them in Chapter 16.

In a context of entanglement, interface norms are likely to reflect the dialectic dynamics in Section 1.4 - strengthening ties between different bodies of norms but preserving discretion or safety valves that help to recalibrate relations in times of tension. ${ }^{74}$ Yet how these norms are construed will often differ across actors. This is most obvious in the jurisprudence of different courts, for example in differences in interpretation of the proper relationship of human rights and international humanitarian law. ${ }^{75}$ But it is at least equally observable outside the courtroom, for example in the conflict over the relationship of the TRIPS (Trade-Related Aspects of Intellectual Property Rights) Agreement with international human rights and world health law as regards access to essential medicines. Here, the World Health Assembly and the (then) UN Human Rights Commission urged an interpretative coupling of the different areas, while neither the WTO's eventual Doha Declaration on the TRIPS Agreement and Public Health nor the implementing decision mention other bodies of law at all - despite the fact that, as a political matter, these other bodies were obviously important for the eventual rapprochement of the WTO ${ }^{76}$ Corradini's chapter on investment and human rights, and Reimers' on trade and environment,

73 See Krisch, Beyond Constitutionalism, pp. 285-96.

${ }^{74}$ In a similar vein, Kjaer highlights the proliferation of 'connectivity norms' in the global order; see P. F. Kjaer, 'Global Law as Inter-contextuality and as Inter-legality', in J. Klabbers and G. Palombella (eds), The Challenge of Inter-legality (Cambridge University Press, 2019), pp. 302-18, at p. 304.

75 See, e.g., A. E. Cassimatis, 'International Humanitarian Law, International Human Rights Law, and Fragmentation of International Law' (2007) 56 International \& Comparative Law Quarterly 623-39.

${ }^{76}$ See on the contest L. R. Helfer, 'Regime Shifting: The TRIPS Agreement and New Dynamics of International Intellectual Property Lawmaking' (2004) 29 Yale Journal of International Law 1 , at $42-5$. 
trace other cases of actors' diverging views over the relationship between two bodies of norms, and they highlight especially the interactive and temporal dimension of the construction of the relationship. Interface norms themselves are contingent: claims about them vary across actors and times. Stable relations between bodies of norms may emerge from convergence among concerned actors on the substance or on the norms governing the interfaces, but such convergence may well prove elusive.

Getting closer to these interfaces means that we cannot limit ourselves to considering the formal rules that govern these relations or the occasional pronouncement of a court - too much of the postnational legal order only has loose connections with courts or other formal dispute settlers. Instead, we need to take into view the ways in which different kinds of actors - norm-makers, addressees, dispute settlers and other concerned societal actors - construe these relations and resolve (potential) conflicts between different norms. We thus need to get closer to the 'social life' of postnational law in order to understand the way it works. ${ }^{77}$ This is brought out in this volume by, for example, Eckert's account of the construction of entanglements 'from below' which zooms in on societal actors and their struggles behind the legal façade, or in Humfress' insistence on a user theory of jurisdiction that starts from the ways in which litigants draw on particular authorities to navigate different layers of law.

The relations brought about through societal action can be a mere matter of fact and influence between different bodies of norms. But they will also often be the result of, and reflected in, discursive statements - in the overlapping bodies of norms themselves or in statements about them from relevant actors. The production of interface norms is then the result not so much of a one-off determination, but of a process of law - a process whose analysis will often benefit from sociological and anthropological methods to complement the work of lawyers, as evident from the multidisciplinary contributions to this volume. ${ }^{78}$

77 See also Taekema's suggestion that a practice orientation is key to understanding interlegality in Taekema, 'Between or Beyond Legal Orders'.

78 See generally S. F. Moore, Law as Process: An Anthropological Approach (Routledge \& Kegan Paul, 1978). 


\subsubsection{Towards a Typology}

What then are the norms and practices that structure the relations between different bodies of norms? Practice has generated a host of tools and approaches in this respect, ${ }^{79}$ and we can distinguish three main types: reception norms, overarching norms and - situated between them - straddling practices. The two former form part of the common repertoire of inter- and intra-systemic norms - they reflect the dichotomy between the (external) conflict of laws and the (internal) conflict of norms ${ }^{80}$ - while the latter blur system boundaries and suggest an alternative structure, characterized by looser couplings.

Reception norms. Reception norms are the typical form through which a legal system deals with norms from the outside; they reproduce the inside/outside distinction and define the ways in which outside norms enter a given body of norms. Michaels' tertiary norms, as developed in Chapter 16, fall into this category as they are designed to regulate the relations of one legal system with others. Reception norms include norms performing an accommodating function in the regulation of the interaction between bodies of norms. ${ }^{81}$ They can reflect closer as well as more distanced relations, though they remain short of actual integration. They can thus range from the exclusion of outside norms to fixed references, potentially coupled with conditions of a procedural or substantive kind. Examples of the latter are conflict-of-law norms that specify in which circumstances foreign norms are applied by national courts; norms about the effect and hierarchical status of outside norms in the domestic legal order; or norms of the Solange kind that recognize the direct effect of (regional or international) norms if these fulfil certain - procedural or substantive - conditions, for example equivalent protection. More flexible reception norms embody greater discretion, for example in requirements of taking norms from other authority spheres 'into account', or in practices granting them 'persuasive authority', thus giving them weight

79 See, e.g., Delmas-Marty, Ordering Pluralism; D. Pulkowski, The Law and Politics of International Regime Conflict (Oxford University Press, 2014); A. Peters, 'The Refinement of International Law: From Fragmentation to Regime Interaction and Politicization' (2017) 15 International Journal of Constitutional Law 671-704.

80 R. Michaels and J. Pauwelyn, 'Conflict of Norms or Conflict of Laws? Different Techniques in the Fragmentation of Public International Law' (2012) 22 Duke Journal of Comparative \& International Law 349-76.

81 See R. Michaels, 'On Liberalism and Legal Pluralism', in M. Maduro, K. Tuori and S. Sankari (eds), Transnational Law: Rethinking European Law and Legal Thinking (Cambridge University Press, 2014). 
but no conclusive effect. ${ }^{82}$ Kanetake's chapter traces the many such forms the United Nations treaty bodies and domestic courts use to calibrate their relations, providing for both linkage and flexibility by using open criteria, such as 'due consideration'.

Overarching norms. Typical for the intra-systemic dimension, overarching norms regulate relations centrally and with binding character for the different bodies of norms involved. This can involve classical conflict norms, such as lex specialis or lex posterior. It can also involve norms about hierarchies, as between constitutions and ordinary statutes or secondary legislation, between federal and state law in federal orders, between ius cogens and other international rules or between obligations under the United Nations Charter and other international obligations under Article 103 of the Charter. Overarching norms can also be construed as substantive integrating rules or principles, such as human rights, sustainable development or democracy/good governance, which create normative expectations throughout the entire system - often expressed, in international law, as rules of 'customary' or 'general' international law. ${ }^{83}$ Equally more flexible are interpretative connections that allow actors space to define relations, such as principles of harmonizing interpretation or requirements not to interpret certain rules 'in isolation' from other parts of the legal order. ${ }^{84}$ On the other hand, overarching rules can also be seen to protect the autonomy of certain parts of the order, through constitutional limits on interference, the recognition of the self-contained character of certain suborders, lex specialis claims or rules which delimit regulatory spheres, as between agreements with different sets of parties.

Straddling practices. The third (and perhaps most interesting) category comprises norms and practices that straddle different bodies of norms without being seen to belong to either, thus blurring the boundaries between them. Given the prevailing systemic imagery, such practices have found less attention so far, even if - as we have seen in the brief historical survey in Section 1.3 - they seem to have formed an important part of the entangled legalities of the past. Such norms and practices will also tend to be less clearly developed and are likely to appear in more inchoate forms. We can observe them, for example, in courts weaving

${ }^{82}$ See also Krisch, Beyond Constitutionalism, pp. 286-96.

${ }^{83}$ See Chapters 7 and 8 by Corradini and Reimers.

${ }^{84}$ See, e.g., C. McLachlan, 'The Principle of Systemic Integration and Article 31(3)(C) of the Vienna Convention' (2005) 54 International and Comparative Law Quarterly 279-320. 
together different bodies of norms in order to come to a solution in a given case. For example, the Court of Appeal of England and Wales, in a case concerning the implementation of UN sanctions, used the notion of 'conciliation' to bring together UK primary and secondary legislation, the European Convention on Human Rights as well as obligations deriving from UN Security Council resolutions in a harmonious fashion, rather than stipulating rules of hierarchy or re-enacting the boundaries between legal systems. ${ }^{85}$ Other boundary-blurring norms may be hybrid norms, multi-sourced equivalent norms ${ }^{86}$ or open concepts used to provide a pathway between different bodies of norms. Examples here include due diligence principles that allow for connections between the national and transnational regulation of multinational companies, or the notion of 'core labour rights' developed by the International Labour Organization and allowing for flexible references in a multitude of other codes, public and private. These forms mirror the 'intertextuality' traced by Mallard and Niederberger in counter-proliferation finance. ${ }^{87}$ Open concepts are also visible in Berger's account of the Bangladeshi Supreme Court's navigation of the boundary between state and religious law (and international human rights).

Such straddling practices are particularly visible in contexts less structured by ideational frames of modern state law. Humfress emphasizes the importance of jurisgenerative practices of actors, rather than formalized norms and relations between them, in the making of law in Chapter 13 on the Eastern Roman Empire. Similar observations pertain to contemporary contexts with a lesser degree of formalization and weaker boundaries than typically found in the state context. Some of the National Contact Points under the OECD Guidelines for Multinational Enterprises, for example, have emerged as quasi-judicial dispute settlement bodies and have drawn on various bodies of norms to ground their findings, as Morochovič and Reimers detail in Chapter 12. Some of the norms they use - such as the requirement of 'free, prior and informed consent' - are drawn from other bodies of norms but used as if they were free-floating principles applicable throughout. Similarly, Duval traces how the Court of Arbitration for Sport uses both publicly and privately

${ }^{85}$ England and Wales Court of Appeal, Judgment of 30 October 2008, A, K, M, Q $~ G$ v. HM Treasury [2008] EWCA Civ 1187.

${ }^{86}$ T. Broude and Y. Shany (eds), Multi-sourced Equivalent Norms in International Law (Bloomsbury, 2011).

${ }^{87}$ See also Kjaer, 'Global Law as Inter-contextuality and as Inter-legality'. 
produced norms in its effort at weaving together lex sportiva's 'tapestry'. Such references build lasting connections between different norms, even in the absence of (systemic) reception norms. We can observe similar phenomena on the regulatory side, as Corradini shows in Chapter 7. The Financial Stability Board (FSB), for example, has sought to connect standards from various transnational and international standard-setters, public and private, formal and informal, through its Compendium of Standards, with fifteen 'key standards' singled out as requiring particular attention. Through the Compendium, the FSB seeks to build a more integrated order out of the existing multiplicity, though one that functions not in the form of a system but through a web with less stable linkages and hierarchies. Other bodies in global financial governance play their part in weaving this web. The resulting structure is not sustained through firm general rules about relations, but rather through contingent, sometimes ad hoc, acts of linking, referencing and distancing, with a potential consolidation occurring only over time. ${ }^{88}$

Another intriguing yet highly challenging form of entanglement is highlighted in Backer's chapter on algorithmic techniques of governance. With the rise of such forms of governance, the linkages between different bodies of norms created through algorithms and ratings become a central concern, and one so far hardly understood. This is especially so as algorithmic governance - just as the many indicators and rankings in contemporary governance in and beyond the state - operationalizes, but typically does not lay open, the normative choices and preferences that go into the weighing of different types of norms and expectations. ${ }^{89}$

\subsection{Entangled Order}

In some of its forms, entanglement can appear as the antithesis of order and system. A multitude of actors producing varying links between norms, sometimes closer, sometimes more distant, but always somehow in flux: this picture seems to be in stark contrast to the ideal of a rule of law. Yet the landscape that emerges from this volume is not as dark or drastic - in many contexts it is quite the opposite.

${ }^{88}$ See also N. Krisch, F. Corradini and L. L. Reimers, 'Order at the Margins: The Legal Construction of Interface Conflicts over Time' (2020) 9 Global Constitutionalism 343-63.

89 See also K. E. Davis, A. Fisher, B. Kingsbury and S. E. Merry (eds), Governance by Indicators: Global Power through Classification and Rankings (Oxford University Press, 2012). 


\subsubsection{Conflict and Consolidation}

Legal entanglement will often be seen as prone to conflict - more clearly defined relations, either the separation or the integration of different bodies of norms, seem to promise greater stability. Stanley Hoffmann's famous dictum about the European Community, which he saw as occupying an unstable middle ground between international cooperation and the creation of a new state, exemplifies this widespread view. ${ }^{90}$ Today, similar assessments often accompany the diagnosis of regime complexity and interface conflicts between different institutions and norms in the global order. ${ }^{91}$

Whether this assumption of conflictivity is empirically justified is not obvious, ${ }^{92}$ however, and how it applies to different forms and degrees of entanglement even less so. Entangled relations do not have to be unstable at all; they can display a high degree of consolidation around the norms that govern interactions. This is especially so if addressees as well as dispute settlers adopt a conciliatory rather than confrontational attitude. ${ }^{93}$ Even if underlying tensions persist, the relative openness of such entanglements, and the frequent accommodation of both linkage and distancing just mentioned, may actually help to provide flexibility and the necessary safety valves to adjust to changing or unforeseen circumstances. $^{94}$

In fact, in several of the chapters in this volume, closer entanglements are construed precisely to respond to, and ward off, challenges to the legitimacy of a certain body of norms. These challenges stem from, for example, human rights (as in Duval's story of the Court of Arbitration for Sport or Corradini's of international investment law) or environmental concerns (as in Reimer's chapter on trade law). On the other hand, more distant entanglement is sometimes sought to defuse conflicts that would be caused by too integrated a relation - as in the move

${ }^{90}$ S. Hoffmann, 'Obstinate or Obsolete? The Fate of the Nation-State and the Case of Western Europe' (1966) 95 Daedalus 862-915.

91 See, e.g., D. W. Drezner, 'The Tragedy of the Global Institutional Commons', in M. Finnemore and J. Goldstein (eds), Back to Basics: State Power in a Contemporary World (Oxford University Press, 2013), pp. 280-310.

92 See C. Kreuder-Sonnen and M. Zürn, 'After Fragmentation: Institutional Density, Regime Complexes and Interface Conflicts' (2020) 9 Global Constitutionalism 241-67.

93 See Peters, 'The Refinement of International Law'; T. Megiddo, 'Beyond Fragmentation: On International Law's Integrationist Forces' (2019) 44 Yale Journal of International Law $115-48$.

94 See Krisch, Beyond Constitutionalism, chapter 7. 
towards a more equal status for Indigenous groups (Chapters 3 and 14 by Anker and Culver and Giudice), or towards greater leeway for national courts vis-à-vis international human rights adjudication (Chapter 6 by Kanetake). Legal entanglement, on the evidence presented here, does not eliminate conflict, but it might help to reduce problems associated with stronger integration or a strict separation of norms that express different, sometimes competing values. It might also, as in Berger's chapter on the struggle over the prohibition of fatwas in Bangladesh, simply help to delay a more principled, clear-cut response to a societal conflict, creating time and space for other processes to do their work.

Once open and contested, interactions between different bodies of norms will also often develop into more settled relations over time. This can be observed, for example, in the evolution of human rightsbased contestation in international economic law which we have traced in an earlier article. What initially appeared as destabilizing challenges of World Bank authority, or earlier corporate social responsibility rules led to an adjustment and transformation which, despite some continuing uncertainties, has led to new consolidation. ${ }^{95}$

\subsubsection{Beyond Legal Systems}

Entanglement also stands in some tension with the way law and legal order have been imagined throughout the past century. Much of the notion of law, inspired by the image of domestic legal systems, was linked to the idea of system - to an orderly structure held together either in form or in content, and distinguishable from its outside. It is the systemic character, brought about by the union of primary and secondary rules, that for H. L. A. Hart and many theorists after him, distinguishes modern law from less developed forms of obligation. ${ }^{96}$ Others, including nonpositivists such as Ronald Dworkin, have focused on coherence and integrity as hallmarks of law. ${ }^{97}$

From all these perspectives, entanglement is a challenge. ${ }^{98}$ It is a limited challenge, at least in formal terms, when we deal with reception

95 Krisch, Corradini and Reimers, 'Order at the Margins'.

96 See only H. L. A. Hart, The Concept of Law (Clarendon Press, 1994); J. Raz, The Concept of a Legal System: An Introduction to the Theory of Legal System (Clarendon Press, 1980).

97 See R. Dworkin, Law's Empire (Harvard University Press, 1986); S. Shapiro, Legality (Harvard University Press, 2011).

98 See also Tamanaha, 'Understanding Legal Pluralism'. 
norms and overarching norms - here, entanglement is integrated into the legal system through the system's own rules about identity and boundaries. Yet even here, the particular rules required to deal with the relations with others have not been overly well theorized. Reception norms, traditionally seen as relatively marginal, pose theoretical problems because, as a matter of fact, they do not operate solely within the system but depend on accommodating rules and practices in other systems. Where interactions between different bodies of norms are intense, the potential for divergences and substantial incoherence grows, posing a challenge for the rule of law aspirations often associated with law, and especially with the systemic image of law. And while a description of law that operates with closure and hierarchies may still have some formal validity (within each of the interacting systems), it captures less of the social reality of a legal order. ${ }^{99}$ In Chapter 16, Michaels draws our attention to the challenge of plurality for a Hartian legal theory and begins to develop a response by introducing 'tertiary' norms and clarifying their scope and functioning. He highlights in particular that such tertiary norms need to reflect a recognition not just from the officials or addressees of the particular legal system concerned but also from other legal systems with which it stands in relations.

The theoretical challenge grows further when we turn to the straddling practices mentioned in Section 1.5. The more these blur the boundaries of different legal systems, the less they can be integrated into a systemic image of the law, even one relying on a multiplicity of systems. The idea of a 'web' - in which different norms, and bodies of norms, form connections with one another, with the whole only emerging from these connections - then becomes yet more attractive. ${ }^{100}$ As Culver and Giudice demonstrate in Chapter 14, such a web may rest on a conceptualization that builds upon but modifies a Hartian approach, by emphasizing mutual references between legal institutions. ${ }^{101}$ This might also provide a frame in which systemic and non-systemic expressions of law can coexist, distinguished primarily by the strength and stability of the connections between particular norms and bodies of norms. Culver and

99 See also the discussion in Taekema, 'Between or Beyond Legal Orders'; G. Palombella, 'Theory, Realities, and Promises of Inter-Legality', in J. Klabbers and G. Palombella (eds), The Challenge of Inter-Legality (Cambridge University Press, 2019), pp. 363-90, at pp. 374-8.

100 F. Ost and M. Van de Kerchove, De la pyramide au réseau?: pour une théorie dialectique du droit (Publications Fac St Louis, 2002).

101 See also Culver and Giudice, Legality's Borders. 
Giudice demonstrate the analytical but also the normative appeal of entanglement over more systemic, hierarchical models by using the example of state-First Nations relations in Canada.

Much theorizing about networks in law, often inspired by Niklas Luhmann's systems theory, has taken the perspective of an external observer, seeking to bring to light the real workings of a social system represented otherwise by the actors involved in it - to reveal 'the hardcore reality of a trompe d'oeil'. ${ }^{102}$ Yet, as our volume shows, a networked reality may well be visible also in the legal discourses themselves. Linkages and entanglements are processed and produced internally to legal practice, through various kinds of norms and practices connecting and straddling different bodies of norms. Often enough, these linkages may connect individual norms, rather than 'bodies' of norms as such, thus taking us yet further away from the notion of closed systems. ${ }^{103}$ A pluralist jurisprudence will then have to give an account of not only the inter-systemic dimension, ${ }^{104}$ but also the trans-systemic, networked character of law, as in Boaventura de Sousa Santos' interlegality. ${ }^{105}$

This is bound to have repercussions on the nature of legal reasoning, well beyond the particular forms of interface norms constructed to deal with the margins. Where actors understand law as a web rather than a hierarchical system, we can expect them to turn away from the ambition of principled solutions - valid throughout the system - and shift towards forms of practical, localized and perhaps provisional accommodation. Inconsistencies within the law are then not so much elements to be eliminated, but instead normal occurrences in an order of multiplicity that need to be processed and navigated. ${ }^{106}$ As indicated by Broude's chapter on the many attitudes of actors towards the entangled legalities they are confronted with, 'navigating' may in any event be a more accurate description of the approach to legal reasoning appropriate in this context. However, as Eckert astutely highlights in her contribution,

102 Teubner, 'The King's Many Bodies', 765.

103 See D. Burchardt, 'Intertwinement of Legal Spaces in the Transnational Legal Sphere' (2017) 30 Leiden Journal of International Law 305-26.

104 This is the dominant perspective in, for example, N. Roughan and A. Halpin (eds), In Pursuit of Pluralist Jurisprudence (Cambridge University Press, 2017).

105 See, e.g., de Sousa Santos, Toward a New Legal Common Sense.

106 See, e.g., H. P. Glenn, The Cosmopolitan State (Oxford University Press, 2013), chapter 14; M. Del Mar, 'Legal Reasoning in Pluralist Jurisprudence', in N. Roughan and A. Halpin (eds), In Pursuit of Pluralist Jurisprudence (Cambridge University Press, 2017), pp. 40-63; Taekema, 'Between or beyond Legal Orders'. 
such a 'navigating' stance (and the turn away from systematicity) may well undermine one of the core sources of hope associated with the law the hope for coherence and universality.

This image suggests a deeper inquiry into the theoretical foundations underlying competing imaginations of law. The contrast between 'postmodern' (complex and multivalent) and 'modern' (orderly and systemic) approaches to law is useful here, ${ }^{107}$ but other directions need to be equally included. Anker's chapter pursues one of these by showing how Indigenous approaches to law have a more natural affinity to entanglement, based on an ontology in which law is merely part of the relations that already exist in symbiotic ecosystems. Taking into view such conceptions of law, and more broadly those animating the historically widespread forms of legal entanglement around the world, should help to situate the image of law in the modern state that most of our jurisprudence has been built around. This image - the systemic, hierarchical and exclusive one - may well constitute the exception rather than the rule.

\subsection{Conclusion}

If law is typically understood in the singular, our focus on entangled legalities traces the implications of its appearance in the plural. Legal multiplicity can, of course, just mean that different legal orders exist side by side, with occasional contact, as in the traditional conflict-of-laws paradigm between national legal orders. But where interactions are more frequent and intense, the relations between different legal orders (and more broadly, different bodies of norms) move to the centre of attention. The legal order as such can then no longer be understood without an account of the ways in which its different parts are entangled. ${ }^{108}$ In this volume, we try to understand the contours of such entanglement better. We ask what entanglement may mean in law and whether it can give a useful account of the relations between different norms, especially in the context of law beyond the state. We try to understand the forms through which actors produce entanglement and what kind of order results from their efforts at weaving norms from different origins together - or at keeping them apart. Entanglement, in our approach, does not denote

\footnotetext{
107 See also D. Burchardt, 'The Twilight of Legal Order? On the Current Challenges Faced by the Concept of a Legal System' (2018) 9 Transnational Legal Theory 110-46.

108 See also Chapters 14 and 16 by Culver and Giudice and Michaels.
} 
merely any form of de facto interaction; it seeks to capture linkages expressed in discursive statements about the relation of multiple norms, namely legal statements about the relations of different norms and legal orders.

We conjecture that in today's globalized world, the burgeoning multiplicity of norms has engendered more entanglement than was the norm in the heyday of consolidated legal orders within nation states. In this respect it may present greater similarities with pre-national legal orders (and continuities with lesser-studied aspects of law in and around modern states) and connect with a neo-medievalist interpretation of the postnational constellation. ${ }^{109}$ Yet this volume is not intended to present a comprehensive empirical picture of legal entanglements in the past or present. It primarily seeks to draw attention to a phenomenon that helps us to observe law differently, and to develop a better understanding of the causes, forms and consequences of this phenomenon. With this, we hope to shift the focus, to begin to see entanglement as a normal state of law, and initiate broader enquiries into entangled legal orders.

109 See J. Friedrichs, 'The Meaning of New Medievalism' (2001) 7 European Journal of International Relations 475-501. 